\title{
An analysis of the relationships between ownership structure and capital structure of the global water industry
}

\author{
$\underline{\text { R. Reza }}^{a}$, G. A. Tularam ${ }^{\text {b,c }}$ \\ ${ }^{a}$ PhD Candidate, Department of Accounting, Finance and Economics, Griffith Business School, Griffith \\ University, Nathan, Qld 4111, Australia \\ ${ }^{b}$ Senior Lecturer in Mathematics and Statistics, Griffith Sciences [ENV], Griffith University, Nathan, Qld \\ 4111, Australia \\ ${ }^{c}$ Environmental Futures Research Institute(EFRI), Griffith University, Nathan, Qld 4111, Australia \\ E-mail:smrajibur.reza@griffithuni.edu.au
}

\begin{abstract}
It is unfortunate but people over the world are living without regular access to safe drinking water. Currently, around $20 \%$ of the world's population ( 1.1 billion people) have about $7 \%$ of its water. Water industry continues to suffer from global shortages, rising consumption levels and importantly, an aging infrastructure). Since water investment has been a challenging sector for making money, water markets across the globe are extending and seeking new opportunities. It is noted that the global water market is worth between US\$400 and US\$500 billion, including US\$175 billion for municipal and industrial water and wastewater capital expenditure. There is an acute need for money and investment in water. Hence, the private sector participation is needed in the water sector but to join the investing in the water industry, private companies need to improve their capital structure. There is however little research regarding the relationships between ownership structure and capital structure of the water industry. This study examines the relationships between ownership structure and capital structure of 72 water companies that comprise the 4 water indices (WOWAX, S-NET, S\&P and MSCI ACWI) over the period 2004-2014 using unbalanced panel (random effects) regression model. The findings of his study shows that investors (foreign and institutional) play an important role to effect the capital structure and investment performance. Foreign ownership affects the leverage and short term debt to asset at the $10 \%$ and $1 \%$ level of significance. However, the Institutional ownership factor does not seem to affect the leverage (LEV) and short term debt to asset (STDA). There are a number of implications for financial managers; types of financial strategies to undertake and thus, determine the optimal capital structure for ownership structure. Individual water investor can cogitate both capital structure and ownership structure when making investment decisions in water industry.
\end{abstract}

Keywords: Global water market, water industry, foreign ownership, institutional ownership, capital structure 
R. Reza and G. A. Tularam, An analysis of the relationships between ownership structure and capital structure...

\section{INTRODUCTION}

Water continues to be a rather critical issue worldwide because of the people over the world are living without regular access to safe drinking water (Reza et al., 2017; Tularam and Reza, 2016). Currently, 20\% of the world's population (1.1 billion people) has only $7 \%$ of its water requirements (Roca et al., 2015; Tularam and Murali, 2015; Tularam and Reza, 2016). Thus, the water industry continues to suffer from global shortages, rising consumption levels and importantly, an aging infrastructure (Roca et al., 2015; Roca and Tularam, 2012; Tularam and Ilahee 2010). In some cases, water shortages are very severe in such as in many regions of North Africa, southern Spain, the Maghreb, Middle East, Central Asia, Bangladesh, Pakistan, Southern India and Northern China (Reza et al., 2017; Roca et al., 2015; Sadoff et al., 2015, Wild, 2010). Recently, variability in precipitation and evaporation patterns have increased due to climate change are expected to have a significant impact on water supply and demand in many regions around the world over the next few decades (Tularam and Reza, 2017; UN-WATER, 2016; Wild, 2010).

Though water has been a challenging sector for investing and making money, water markets across the globe are extending their opportunities by approaching in novel ways. The global water market is worth between US\$400 and US\$500 billion, including US\$ 175 billion for municipal and industrial water and wastewater capital expenditure (Global Water Intelligence, 2007; Wild et al., 2010). The future investment in water industry needs more than that provided by governments alone. Hence, more private investment is needed to invest in water industry. However, for them to be attracted to water industry, there are a number of changes that is needed; for example, the private companies need to improve their capital structure. Investors (foreign and institutional) play an important role as they influence the capital structure and investment performance. It is noted that a number of global institutional investors have started to take such a challenge (Roca and Tularam, 2012). Importantly, the ownership structure and leverage are two important aspects in the governance of firms that need attended when considering such new markets (Mukonyi et al.; 2016). After the global financial crisis (GFC) period, most of the firms changed their corporate governance by noting that the ownership structure and capital structure influence important decisions made in private organizations. The objective of this study is to examine the relationships between ownership and capital structure of the many water companies around the globe for the period of 2004-2014. A financial panel type time series approach is taken to examine the nature of relations and interactions between the water companies and investment performance.

This study makes two significant contributions to the current literature. Firstly, this study helps to exploration the effect of various corporate governance and capital structure related reforms which are introduced in the global water sector. Secondly, this is the first study to examine the nature of the relationships between the ownership and capital structures of the global water industry.

The rest of this paper is organized as follows. Section 2 reviews the related literature- between the relationship between ownership and capital structure. Section 3 presents the data and methodology. Section 4 discusses the empirical results/discussion and conclusions are given in Section 5.

\section{LITERATURE REVIEW}

In the finance literature, several studies have focused on the relationships between ownership and capital structure in different sectors around the world. For example; Mahrt-Smith (2002) investigated the interaction effects of the capital structure and ownership structure in manager-run corporations. The results show that equity ownership is strongly linked concentrated debt holdings. In contrast, Driffield et al. (2007) found the opposite result that shows a negative relationship exists between the ownership and capital structure using 3SLS models.

In terms of leverage, Céspedes et al. (2009) claimed that there is a higher leverage in Latin American firms. They use 806 nonfinancial Latin American firms from 1996 to 2005 and examine how ownership concentration affects capital-structure decisions in Latin America using balanced panel (fixed effects) regression model. They found relations between leverage and ownership to be significant, positive and highly correlated. Similarly, Li et al. (2009) studied the interaction between ownership structures and institutions' effect on leverage decisions for the 417,068 Chinese firms during the period between 2000 and 2004 using fixed effects model. They found state ownership has a positive impact on leverage; and firm access to long term debt. However, foreign ownership was negatively linked with all measures of leverage.

Further, Yarram (2013) investigated the association between ownership structure and capital structure of 465 Australian firms for the period 2004 to 2010 using ordinary least square (OLS) models. The results show a significant non-linear relationship between ownership and capital structure. Farooque (2015) examined how 
R. Reza and G. A. Tularam, An analysis of the relationships between ownership structure and capital structure...

the ownership concentration affects capital structure of MENA region firms for the period of 2005-2009) using pooled regression analysis. His results show that ownership concentration negatively affects capital structure. In a recent study, Mukonyi et al. (2016) studied the relationships between ownership structure and leverage of 46 Kenyan firms during the period between 2006 and 2014 using multiple regression analysis. They found out a weak positive relationship between state ownership and leverage.

There is a gap in the literature concerning the nature of such relations in the global water industry and this study fills this gap by examining in depth the relationships between ownership structure and capital structure in the water industry for the period of 204-2014 using unbalanced panel (random effects) regression model.

\section{DATA AND METHIDOLOGY}

\subsection{Data}

This study utilizes 72 water companies that are covers four most important and recognized water indices; these are World Water Index (WOWAX), S-Network Global Water Index (S-Net), S\&P Global Water Index (S\&P), MSCI ACWI Water Utilities Index (MSCI ACWI). The 72 companies are listed in different stock markets worldwide such as the New York Stock Exchange, Toronto Stock Exchange, London Stock Exchange, Euro Next Paris, Helsinki Stock Exchange, Shanghai Stock Exchange, Tokyo Stock Exchange, Korea Stock Exchange, Philippine Stock Exchange, and Stock Exchange of Singapore for the period 2004-2014. Dependent, independent and control variables data of 72 water companies are collected from Bloomberg and OSIRIS.

\subsection{Methodology}

In terms of time series, to investigate the relationship between ownership and capital structure of water companies in the WOWAX, S-Net, S\&P and MSCI ACWI over a period of eleven years, this research uses the unbalanced panel (Random effects) regression model by the studies of Roca et al. (2015).

$$
\text { CAPITAL_STRUCTURE }_{\mathrm{it}}=\beta_{0}+\beta_{1} \text { FOROWN }_{\mathrm{it}}+\beta_{2} \text { INTOWN }_{\mathrm{it}}+\mathrm{Z}_{\mathrm{it}}+\varepsilon_{\mathrm{it}}
$$

where capital structure is a dependent variable and is measured by leverage (LEV) and short-term debt to total assets (STDA); and foreign ownership (FOROWN), institutional ownership (INTOWN), are dependent variables; $Z_{i t}$ is a set of firm-level control variables and random error component, $\varepsilon_{i t}$. Table 1 defines the variables which are used in the random effects model.

Table 1. Descriptions of the variables

\begin{tabular}{lll}
\hline \multicolumn{1}{c}{ Variable name } & \multicolumn{1}{c}{ Notation } & \multicolumn{1}{c}{ Description } \\
$\begin{array}{l}\text { Capital structure } \\
\text { Leverage }\end{array}$ & LEV & Total debt to total assets \\
$\begin{array}{l}\text { Short-term debt to total assets } \\
\text { Ownership structure }\end{array}$ & STDA & Short-term liabilities divided by total assets \\
$\begin{array}{l}\text { Foreign ownership } \\
\text { Institutional ownership }\end{array}$ & FOROWN & Percentage of shares owned by foreign shareholders \\
$\begin{array}{l}\text { Control variables } \\
\text { Tangibility }\end{array}$ & INSTOWN & $\begin{array}{l}\text { Percentage of shares owned by institutional investors } \\
\text { Asset Growth }\end{array}$ \\
& TANGIBILITY & Fixed tangible assets divided by the total assets \\
Return on assets & GROWRH & $\begin{array}{l}\text { Percentage growth in depreciation-adjusted total } \\
\text { assets from end of year t-2 to end of year t-1 }\end{array}$ \\
Risk & ROA & Net income divided by total asset \\
Age & RISK & Standard deviation of stock returns \\
\hline
\end{tabular}


R. Reza and G. A. Tularam, An analysis of the relationships between ownership structure and capital structure...

\section{EMPIRICAL RESULTS}

\subsection{Descriptive Statistics}

From Table 2, it can be seen that mean returns are positive for dependent, independent and control variables. The largest positive mean return (56.232) is for AGE whereas the STD has the lowest positive mean return (0.051). As the skewness values of LEV, STD, FOROWN INSTOWN, TANGIBILITY, GROWTH, RISK and AGE are in general positive-symmetric tail, whereas the skewness values of ROA are negative i.e. the asymmetric tail. The kurtosis values of all variable are higher than three except LEV and INSTOWN. Thus the returns distribution could be fat-tailed except LEV and INSTOWN. Since the Jacque-Bera results are statistically significant and reject the null hypothesis of a normal distribution for all variables. Nonetheless, our analysis is robust as models are usually robust as well in non-normal cases because linear regression is usually rather robust in many cases (Tularam and Reza, 2017). Figure 1 presents the trends of leverage (LEV) and short-term debt to total assets (STDA) of global water companies' for the period of 2004-2014 and Figure 2 shows the trends of foreign ownership (FOROWN) and institutional ownership (INTOWN) of global water companies' for the period of 2004-2014.

Table 2. Descriptive statistics

\begin{tabular}{|c|c|c|c|c|c|c|c|c|c|}
\hline & LEV & STDA & FOROWN & INSTOWN & TANGIBILITY & GROWTH & $\mathrm{ROA}$ & RISK & AGE \\
\hline Mean & 24.308 & 0.051 & 16.703 & 46.097 & 26.717 & 19.243 & 5.049 & 15.046 & 56.232 \\
\hline Median & 23.888 & 0.027 & 12.630 & 46.535 & 22.427 & 6.398 & 5.439 & 1.079 & 38.000 \\
\hline Maximum & 83.440 & 0.443 & 95.800 & 99.050 & 91.005 & 2198.446 & 38.440 & 266.347 & 239.000 \\
\hline Minimum & 0.000 & 0.000 & 0.000 & 1.250 & 0.000 & -65.414 & -70.100 & 0.000 & 1.000 \\
\hline Std. Dev. & 16.640 & 0.063 & 14.904 & 23.769 & 23.693 & 115.428 & 8.052 & 26.328 & 48.805 \\
\hline Skewness & 0.2980 & 2.085 & 1.545 & 0.167 & 1.000 & 14.394 & -3.171 & 3.256 & 1.474 \\
\hline Kurtosis & 2.308 & 8.639 & 6.291 & 2.171 & 3.231 & 235.529 & 27.35870 & 20.245 & 4.875 \\
\hline Jarque-Bera & 25.682 & 1516.821 & 628.708 & 24.612 & 125.014 & 1692708. & 19535.23 & 10477.84 & 376.469 \\
\hline Probability & 0.000 & 0.000 & 0.000 & 0.000 & 0.000 & 0.000 & 0.000000 & 0.000 & 0.000 \\
\hline Sum & 17988.48 & 37.817 & 12360.92 & 34112.32 & 19770.95 & 14240.36 & 3736.916 & 11134.56 & 41612.00 \\
\hline Sum Sq. Dev. & 204641.4 & 3.017 & 164172.8 & 417532.1 & 414846.6 & 9846280. & 47917.92 & 512254.4 & 1760270 . \\
\hline Observations & 740 & 740 & 740 & 740 & 740 & 740 & 740 & 740 & 740 \\
\hline
\end{tabular}

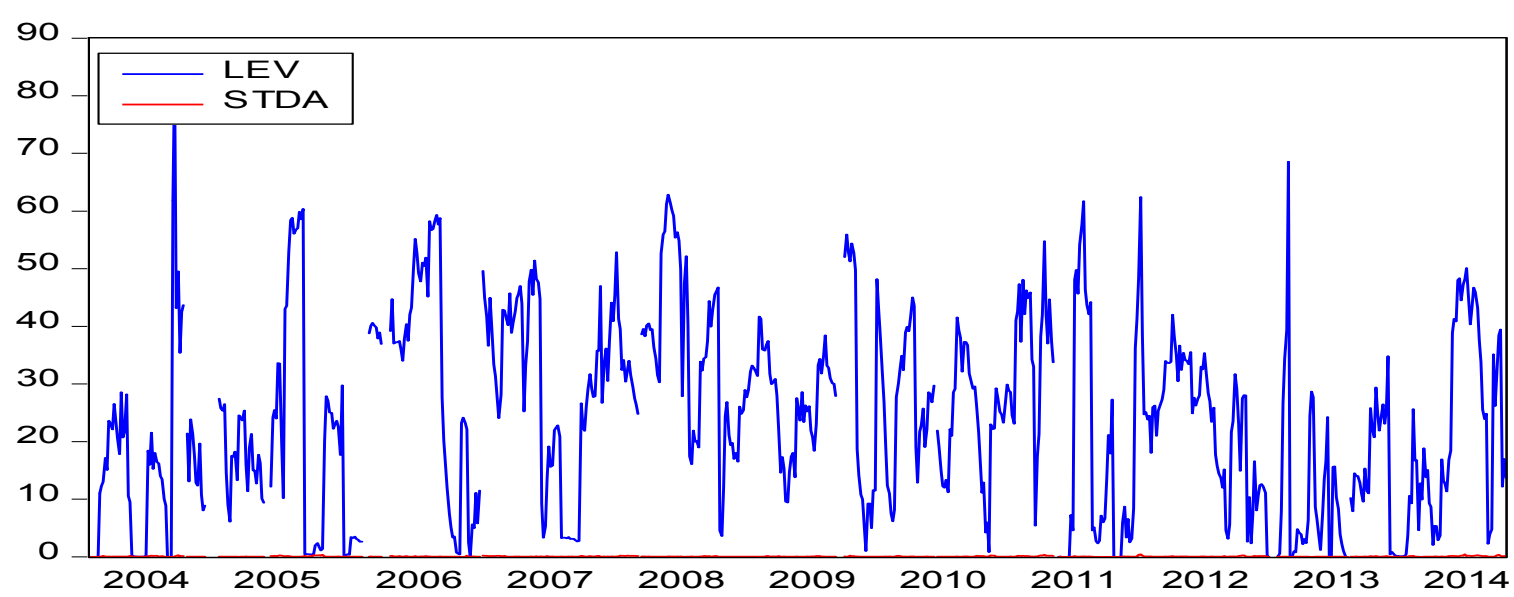

Figure 1. Trends of leverage (LEV) and short-term debt to total assets (STDA) for the period of 2004-2014. 


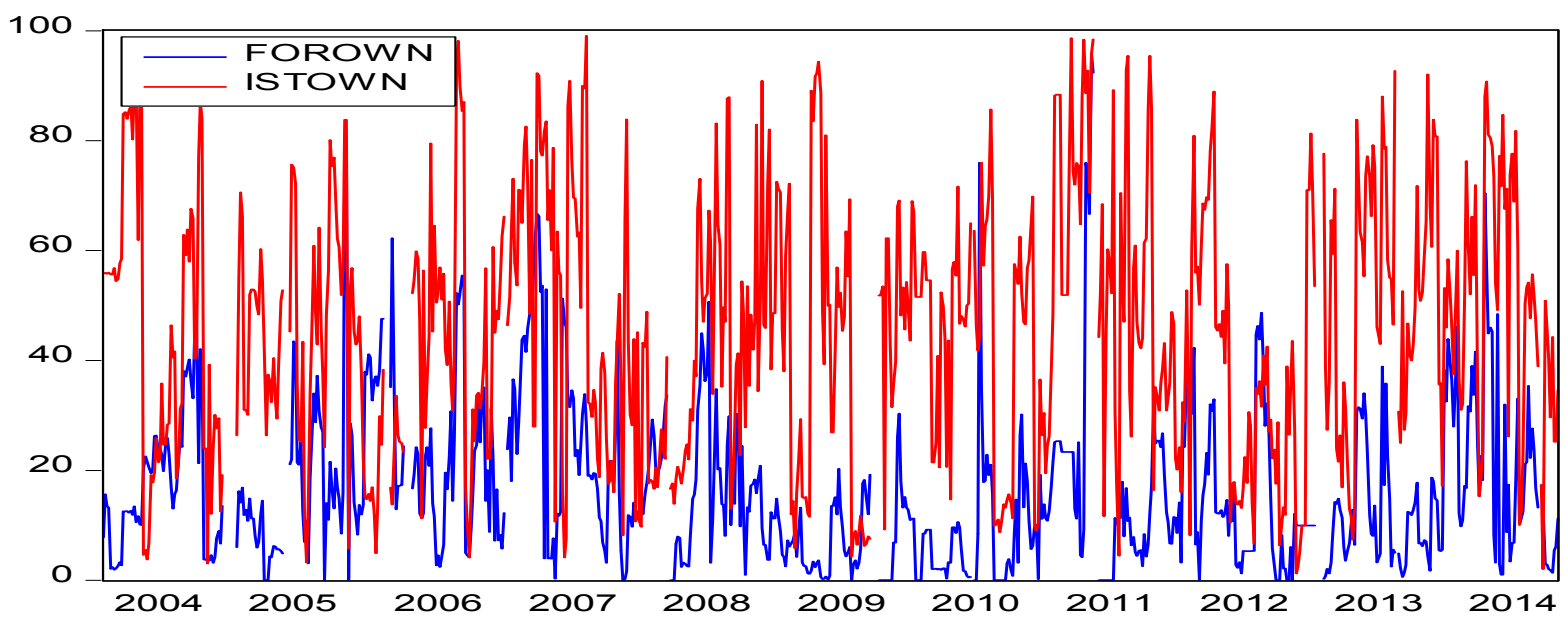

Figure 2. Trends of foreign ownership (FOROWN) and institutional ownership (INTOWN) for the period of 2004-2014

\subsection{Analysis based on correlations}

Table 3 presents the correlation matrix between dependent, independent and control variables. The matrix shows a positive correlation between ownership (FOROWN, and INSTOWN) and capital structure (LEV and STDA). It is noted that the highest simple correlation between independent variables is 0.099 between foreign ownership (FOROWN) and leverage (LEV). The results show that the correlation coefficients between independent variables do not exceed 0.8 or 0.9 . Thus, the results are consistent with Bryman and Cramer (1997). In addition, in a multivariate setting, the average variance inflation factor (VIF) of 1.65 is close to 2 which suggests that multicollinearity between the independent variables does not pose a serious problem because the average VIF is not substantially greater than 10 .

Table 3. Correlation matrix of the variables

\begin{tabular}{|c|c|c|c|c|c|c|c|c|c|}
\hline & LEV & STDA & FOROWN & INSTOWN & TANGIBILITY & GROWTH & $\mathrm{ROA}$ & RISK & AGE \\
\hline$\overline{\mathrm{LEV}}$ & 1 & & & & & & & & \\
\hline STDA & 0.301 & 1 & & & & & & & \\
\hline FOROWN & 0.099 & 0.077 & 1 & & & & & & \\
\hline INSTOWN & 0.067 & 0.032 & 0.262 & 1 & & & & & \\
\hline TANGIBILITY & 0.194 & 0.039 & 0.070 & -0.024 & 1 & & & & \\
\hline GROWTH & 0.159 & 0.022 & 0.081 & 0.051 & -0.079 & 1 & & & \\
\hline ROA & -0.117 & -0.142 & 0.041 & -0.045 & 0.125 & -0.025 & 1 & & \\
\hline RISK & 0.036 & 0.256 & -0.034 & 0.153 & -0.035 & 0.053 & -0.175 & 1 & \\
\hline AGE & -0.228 & -0.064 & -0.051 & -0.172 & -0.019 & -0.095 & 0.186 & -0.095 & 1 \\
\hline
\end{tabular}

\subsection{Regression Analysis}

We estimate equation (1) using the unbalanced panel (Random effects) regression model. We choose random effects model and using it, we examine the nature of relationships between capital structure and ownership structure. Tables 4-5 show that the estimated coefficients are positive and foreign ownership significantly affect the leverage (LEV) at the $10 \%$ level. Again, foreign ownership is also significantly correlated with STDA at $1 \%$ level of significance. Thus, it is important to note that foreign ownership only individually impact on the capital structure. But, Li et al. (2009) found out a negative association between foreign ownership and leverage. We also find out that the institutional ownership does not affect the leverage and STDA any level of significance. 
R. Reza and G. A. Tularam, An analysis of the relationships between ownership structure and capital structure...

As control variables denote to contributing factors that are fixed or eliminated in order to examine the relationship between an independent variable and a dependent variable; thus, control variables strongly influence experimental results. In the table 4, the results show that TANGIBILITY, and GROWTH positively affect the leverage (LEV) at the 1\% level of significance. However, ROA and AGE are negatively correlated with LEV at the $5 \%$ and $1 \%$ level of significance respectively. In the table 5 , it can be seen that TANGIBILITY and AGE are significant with STDA at the 5\% and $1 \%$ level respectively whereas ROA negatively impacts on STDA at the $1 \%$ level of significance.

Table 4. Regression results of LEV on FOROWN and ISTOWN

\begin{tabular}{lcc}
\hline \multicolumn{3}{c}{ Dependent Variable: Leverage } \\
\hline Independent Variable & Coefficient & Probability \\
\hline FOROWN & 0.074 & $0.082^{*}$ \\
INSTOWN & 0.005 & 0.679 \\
TANGIBILITY & 0.148 & $0.000^{* * *}$ \\
GROWTH & 0.021 & $0.000^{* * *}$ \\
ROA & -0.235 & $0.050^{* *}$ \\
RISK & -0.000 & 0.959 \\
AGE & -0.063 & $0.000^{* * *}$ \\
Intercept & 23.232 & $0.000^{* * *}$ \\
\hline Observations & 740 & - \\
\hline
\end{tabular}

Note: $* * *$ and $* * *$ represent significance at $10 \%, 5 \%$ and $1 \%$ levels respectively.

Table 5. Regression results of STDA on FOROWN and ISTOWN

\begin{tabular}{lcc}
\hline & Dependent Variable: STDA \\
\hline Independent Variable & Coefficient & Probability \\
\hline FOROWN & 0.000 & $0.001^{* * *}$ \\
INSTOWN & -0.000 & 0.276 \\
TANGIBILITY & 0.000 & $0.057^{* *}$ \\
GROWTH & 1.316 & 0.946 \\
ROA & -0.000 & $0.004^{* * *}$ \\
RISK & 0.000 & $0.000^{* * *}$ \\
AGE & 0.000 & 0.425 \\
Intercept & 0.042 & $0.000^{* * *}$ \\
\hline Observations & 740 & - \\
\hline
\end{tabular}

Note: $* * *$ and $* * *$ represent significance at $10 \%, 5 \%$ and $1 \%$ levels respectively.

\section{CONCLUSION}

The objective of this study is to examine the relationship between ownership structure and capital structure of a sample of 72 water companies around the globe for the period of 2004-2014. Using unbalanced panel (random effect) regression model, we find a statistically significant positive relation between leverage and foreign ownership as well as STDA and foreign ownership of 72 water companies which is consistent with expectations. This result suggests that foreign ownership is more effective in corporate governance and performance of global water companies because foreign ownership are susceptible to reduce the agency problems as well as 'free-riding' problems.

The results of this study are suitable for financial managers to take the financial strategy and decide the optimal capital structure for ownership structures as well as water investor can cogitate both ownership and capital structure when they will take their investment decisions in water industry. Further, this research study can be 
R. Reza and G. A. Tularam, An analysis of the relationships between ownership structure and capital structure...

extended along with a complementary investigation on the relationship between corporate governance (Board of directors and ownership concentration) and capital structure to examine how corporate governance influences corporate decision-making which, in turn, impacts firm characteristics such as leverage, Long-term debt to total assets and Short-term debt to total assets in different (full, pre-GFC, GFC and post-GFC) periods.

\section{REFERENCES}

Bryman, A., and Cramer, D. (1997). Quantitative Data Analysis with SPSS for Windows, Routledge, London.

Cespedes, J., Gonzalez, M., and Molina, C.A. (2010). Ownership and capital structure in Latin America, Journal of Business Research, 63(3), 248-254.

Driffield, N.L., Mahambare, V., and Pal, S. (2007). How does ownership structure affect capital structure and firm value? Recent evidence from East Asia, Economics of Transition, 15(3), 535-573.

Farooq, O. (2015). Effect of ownership concentration on capital structure: evidence from the MENA region, International Journal of Islamic and Middle Eastern Finance and Management, 8(1), 99-113.

Global Water Intelligence (2007). Global Water Market 2008, Oxford, UK.

Li, K., Yue, H., and Zhao, L. (2009). Ownership, institutions, and capital structure: Evidence from China, Journal of comparative economics, 37, 471-490.

Mahrt-Smith, J. (2005). The interaction of capital structure and ownership structure, Journal of Business, 78, 787-816.

Mukonyi, P. Basweti, K., and Kamau, S. (2016). The Relationship between Ownership Structure and Leverage of Firms Listed in the Nairobi Securities Exchange, IOSR Journal of Economics and Finance, 7(3). 52-59.

Reza, R., Tularam, G. A., and Li, B. (2017). An investigation into the interdependence of global water indices: a VAR analysis, Applied Economics, 49(8), 769-796.

Roca, E. D., and Tularam, G. A. (2012). Which way does water flow? An econometric analysis of the global price integration of water stocks, Applied Economics, 44, 2935-2944.

Roca, E., Tularam, G. A., and Reza, R. (2015). Fundamental signals of investment profitability in the global water industry, International Journal of Water, 9, 395-424.

Sadoff, C. W., Hall, J. W., Grey, D., Aerts, J. C. J. H., Ait-Kadi, M., Brown, C., Cox, A., Dadson, S., Garrick, D., Kelman, J.,McCornick, P., Ringler, C., Rosegrant, M., Whittington, D., and Wiberg, D. (2015). Securing Water, Sustaining Growth: Reportof the GWP/OECD Task Force on Water Security and Sustainable Growth. UK, University of Oxford. Accessed July 10 2017. http://www.water.ox.ac.uk/wpcontent/uploads/2015/04/SCHOOL-OF-GEOGRAPHY-SECURING-WATER-SUSTAININGGROWTH-DOWNLOADABLE.pdf

Tularam, G. A., and Illahee, M. (2010). Time series analysis of rainfall and temperature interactions in coastal catchments, Journal of Mathematics and Statistics, 6, 372-380.

Tularam, G. A., and Murali., K.K. (2015). Water Security Problems in Asia and Longer Term Implications for Australia, In Sustainable Water Use and Management, edited by Filho, W. L. and V. Sümer, 119-149. Switzerland: Springer International Publishing.

Tularam, G. A., and Reza, R. (2017). The Critical Importance of Groundwater in Coastal Areas: Impact of Climate Change on Bangladesh Freshwater Resources, Journal of Climate Change, 3, 59-70.

Tularam, G.A., and Reza, R. (2016). Water exchange traded funds: A study on idiosyncratic risk using Markov switching analysis, Cogent Economics \& Finance, 4, 1-12.

UN-WATER. (2016). Water and Jobs, The United Nation World Water Development Report. Accessed July 12 2017. Accessed July 8 2017. http://unesdoc.unesco.org/images/0024/002439/243938e.pdf

Wild, D., Francke, C.J., Menzli, P., and Schon, U. (2010). Water: A market of the future. Zurich: SAM Sustainable Asset Management. 